\title{
Formation of Linguistic Culture of Pupils by Working with Vocabulary
}

\author{
Doc. Dr. Kledi Satka (Shegani) \\ University of Tirana, Faculty of History and Philology, Linguistics Department \\ Email: kshegani@yahoo.com \\ Doc. Dr. Albana Deda (Ndoja) \\ University of Tirana, Faculty of History and Philology, Linguistics Department \\ Email: albanandoja@hotmail.com
}

\section{Doi:10.5901/jesr.2015.v5n1s1p57}

\begin{abstract}
The main purpose of educationin the elementary school is that the pupils gets the basics of thinking and speech development and to create conditions for the formation of different concepts. For this reason, in this initial period of child's education, it is of first importance the work of vocabulary which is directly connected with the addition of images of the child for the physical and social environment that surrounds him, the exercice of speech and addition of the active reserve of the vocabulary of the pupils. This process essentially realizes the organization of thoughts, multiplies and optimizes social, emotional, communicative and cognitive behavior by mobilizing all the energies of the child and identifying specific trend in the formation of everyone. Highlighting examples from the work of teachers with vocabulary, as a means to stimulate imagination and logical thinking, we will try to analyze the primary role of the culture of the word, which is considered foremost as a precise expression of different images and concepts. The most effective method is exactly the one that gives priority to the continuos and systematic discovery of connections of word and imagination, object and image in order for them to enter the consciousness of pupils not as separate things, but as systematic knowledge of reality and of denominations or ways of saying that serve them to express themselves.
\end{abstract}

\section{From $A$ to $Z$ of the Culture of Language (From the First Letter of the Alphabet to the Last Letter)}

Development and learning are the result of the interconnection of the biological maturity and environment, including the social and cultural world where the child lives.

From $A$ to $Z$ of the culture of language, the child progresses to practice new skills gained from experience and motivated by learning through social interaction and relationships with others. Work for establishing pupils' culture of speaking first presupposes continuous perfection of their ability to use the mother language in all forms of its practical implementation, both orally and in writing. ${ }^{1}$

The main purpose of education in the elementary school is that the pupil gets the basics of thinking and speech development and to create conditions for the formation of different concepts. For this reason, in this initial period of child's education, it is of first importance the work with vocabulary, which is directly connected with the addition of images of the child for the physical and social environment that surrounds him, the exercise of speech and addition of the active reserve of the vocabulary of the pupils. Education in fact can not be considered only as a technical issue through which information is processed, it is a complex activity, which tries to adapt the culture with the requirements of members of a society, but on the other hand also adapt their knowledge to the requirements of this culture. ${ }^{2}$

Work with dictionary should be extended to all subjects. This is for the simple reason that the contact of children with the language of books leaves multiple traces and sometimes we encounter mechanical use of words or analogous construction of nonexistent words. For example a child, after hearing the tale of shark "peshkaqen", addressed teacher with the words: "Now tell us a tale with "peshkamace". Such examples show that in the first two years of elementary school, children are still associated with a talk where frequently are used words that do not express their imagination,

\footnotetext{
${ }_{1}$ Gjokutaj,M., Gjendja dhe perspektivat e zhvillimit të lëndës së gjuhës shqipe në shkollën tetëvjeçare, në "Kurrikula dhe shkolla", Gjuhë shqipe dhe leximi letrar, 5, Tiranë, 2003,f.62-82.

2 Bruner J.,La cultura dell'educazione, nuovi orisonti per la scuola, Fetrineli Editore, 2000, faqe 56
} 
sometimes even contradict the linguistic facts. The semantic link of the word star (like orb: Morningstar, the stars are in the sky; the star as a symbol of a five-corner sign: the starfish, it is a star "is beautiful", was born with a star "lucky") is among the simple links, but for a child it is not so simple to make the linguistic link be responsive to his imagination. The child who already knew the word star like orb that looks only at night, listening to the starfish word asked the question: why was night at the sea?

The child is thus expanding the meaning of the words already learned. For example, he may have learned the word "first" because he himself is in the first class. Now, he is learning that the same word can have other meanings, such as to be first in the queue, or the first letter of a book. In its entirety, the system of understanding of the child, thus the semantics, not only grow in size, but also deepens the meaning at the same time.

\section{Word and Image}

Lexicon can be considered as a kind of "mental dictionary" in which a person has stored the words from an early age, the amount of which increases progressively over the years. From this "dictionary" we take whenever we need the word and put it in the right lexical and semantic context. According to Bruner, intellectual development is influenced by the way in which human beings gradually learn to present the world through action, image and symbol3.

The most effective method is exactly the one that gives priority to the continuous and systematic discovery of connections of word and imagination, object and image in order for them to enter the consciousness of pupils not as separate things, but as systematic knowledge of reality and of denominations or ways of saying that serve them to express themselves. The culture of speech is therefore, first and foremost, the precise expression of various images and concepts. From the observed examples we have noticed that children have established with the language a report, which in its early stages passes through notional grammar, which is the frame of reference within which the child starts to move by dealing with language. According to Deon, ${ }^{4}$ the starting point is the so-called "notional grammar", exactly the grammar which consists of basic concepts that are close to the child (movement, time, eating, etc. ), and serve as points of reference in linguistic logical flow while the child reaches its full disposition, transmitting meanings that are channeled according to available means of a language and to child development in its linguistic environment.

Child's personality, his intelligence and expressive language are developed step by step in conjunction with adults, peers and the environment where he is living. Efforts for culture of speech are in fact attempts for the culture of child's thinking, for the education of his images and imagination.

Relying on intuitive knowledge of the child is important for two reasons: the first is the motivation: when children have their own theories about the process, means that they are interested in the problem in question and have overcome the stage of a simple description of the problem. The second relates to the value of education in the development of thinking of a child; towards a logical understanding.

Practice has shown that generally in the children of first classes there are quite a lot of discrepancies between the word and its imagination. Sometimes children have images, but not enough words to express. This is because the word is learned without knowing the meaning or it is connected with an inaccurate and incomplete image.

To enrich the vocabulary of pupils, it is important the course of knowledge of nature, through which children become acquainted with nature, environment and society, even through concrete observations, excursions and experiments, so that for each new word, pupils form strong links with what it is called. Thus, there is the possibility to have complete sensations and perceptions of objects, objects and their properties. When the pupil has never seen an object, it is difficult or impossible to visualize it.

It is clear that the teacher to expand the vocabulary of pupils must rely on the experience of the pupils, in familiar things to them, but always, this experience or knowledge of the essence and characteristics of various items must be enriched with other knowledge. The more obvious are the images of objects that pupils study the stronger and the stable will be links of the word with its meaning, and the greater will be the opportunities for uses of figurative and semantic extensions of the type of polisemy. This regards, of course, to the fact that the recognition of nature, of its objects and phenomena is endless; it is added and continuously enriched with new details, through which also comply the related names. Thus for example the words: bear, roaring, fences teeth, tearing etc. children may have heard and learned even before they enter school, through their parents' stories, tales, conversations with adults etc. but their understanding get clear only when they visit the zoo, or see a teaching movie etc. where they notice specifically what they have heard of it.

Another way is reliance in the description given in the dictionary of Albanian language, in presenting their

\footnotetext{
${ }^{3}$ Bruner J.,La cultura dell'educazione, nuovi orisonti per la scuola, Fetrineli Editore, 2000

${ }^{4}$ Deon V., La grammatica suggerita dai bambini në Italiano e Oltre Nr. 4, 1993
} 
similarities and differences from other types of relevant gender. In this case it is child's imagination to perform the connection of new meanings to those well known, so it happens often that images for new objects are not be the same for all pupils in a class, they differ, being close or far from the truth, depending on the clarity of the explanation presented, but also the experience of personal knowledge of each one. Thus for ex. in the course of the Knowledge of Nature the pupils faces the phrase spaceship. Different pupils in different areas visualize this word in different ways, depending on the knowledge and experience acquired previously. Those who live in coastal cities, of course, have a better knowledge of ships, their size and type, hence the name of the new spaceship is for them more accessible to the imagination; this can be said for those who have seen the documentary and films concerning sea, ships etc., and is quite elusive for those residing in different areas, non close to the coast, especially in remote mountain areas.

In cases like this, when the child's is enriched with new words through the mediated images, illustrations are an important element in the enrichment of child's vocabulary. This relates primarily with the generalized character of different denominations. For example the word animal used in the course of Knowledge of Nature should be understood by children as comprising all kinds of animals, wild or domestic, although they can be very different from the appearance, size and way of living.

Thus, knowledge of nature is the course through which pupils enter deeply into polisemy and homonymous and synonymous richness of Albanian language.

Words such as: world, block, bloom, subject, leaf, smell, etc. ., should take all their breadth of meaning, so that the name is associated with clear images. For the meanings of the verb bloom "cel" are effective compound words such as: çel derën, çelin lulet, çelem në fytyrë, çelën zogjtë, çeli koha etc.

Of course that explanation of the meanings and the difference between them will not be so metalinguistic, but mainly through getting free compound words or sustainable typical for the respective meanings.

Exactly by phrases and sentences which consist of compound words that are of interest us, the child not only knows polisemy of words, but also the penetration of figurative expressions and of different shades of stylistic value. Thus for example for the word erë, (smell/wind) through sentences in which it is contained: a strong wind blows; autumn wind, windy spring; smell the flower; good smelling, stink; etc. , it is made the distinction of its first meaning "wind" from the second meaning: "fragrance"; on the other hand, precisely through compound words that explain the second meaning, fragrance (as good smell, stink, flower smell) it is created the opportunity to understand the phraseology "it smells" "the trick is understood, the secret is revealed".

\section{Conclusions}

In conclusion to the discussion and examples that we brought above, we can say with conviction that the language of children should be considered as the foundation of formatting a human personality, which runs from stuttering and babytalk to the imagination and processed and logical thinking. Nowadays, everywhere in the world, and also in Albania, as a result of increased incentives of "electronic discourse" (games with sounds, words, and musical sounds etc. ) and the cartoons that are provided by television channels, videotapes or DVDs, it is observed an acceleration of the overall mental and linguistic development of children.

It is necessary to expand more the concept of forming linguistic culture to pupils considering these basic directions:

a) Enriching morphological system of speaking to pupils with a sufficient amount of different parts of the lecture (names, adjectives, verbs, pronouns, adverbs, prepositions, conjunctions, particles, exclamations);

b) Processing and clarification of difference between the words of the same root and words with similar roots;

c) Enriching pupils' speaking, i. e. recognition of such categories of words such as synonyms, antonyms, homonymy, epithets, comparisons, phraseology and sustainable compound words equivalent to a word or term etc.

This process essentially realizes the organization of thoughts, multiplies and optimizes social, emotional, communicative and cognitive behavior by mobilizing all the energies of the child and identifying specific trend in the formation of everyone.

\section{References}

Shkurtaj, Gj. , (2003) Sociolinguistika, SHBLU ,Tiranë.

Shkurtaj Gj. (2004) Etnografi e të folurit të shqipes, SHBLU, Tiranë.

Jerome,B. , (2002), La cultura dell'educazione, nuovi orisonti per la scuola, Fetrineli Editore. 
Marazzini C. , (2001) II perfetto parlare. La retorica in Italia da Dante a Internet, Roma, Carocci.

Deon V. , (1993) La grammatica suggerita dai bambini në Italiano e Oltre Nr. 4.

Pontecorvo, C. , Ajello, A. M. Zucchermaglio, C. (1995). I contesti sociali dell'apprendimento. Acquisire conoscenze a scuola, nel lavoro, nella vita quotidiana, Milano, Ambrosiana.

Fishman J. , (1965) Who speaks, what language, to whom and when, "La linguistique"2.

Koutsouvanov, E. , (1993) Television and child language development, International Journal of Early Childhood 25 f. 27-32.

Buzan, T. , (2006) Truri i fëmijës, Botimet "Max".

Gjokutaj, M. , (2003), Gjendja dhe perspektivat e zhvillimit të lëndës së gjuhës shqipe në shkollën tetëvjeçare, në "Kurrikula dhe shkolla", Gjuhë shqipe dhe leximi letrar, 5, Tiranë. 